\title{
DATING VIOLENCE: A REPORT FROM LEGAL AND VICTIMOLOGICAL PERSPECTIVE
}

\author{
Salimi Muhammad Baindowi* \\ Women Protection and Family Law Research Center, Surabaya, Indonesia \\ *Email: salimibaindowi@gmail.com
}

\begin{abstract}
Violence against women is a manifestation of the historical inequality of power relations between men and women. This results in the emergence of domination and discrimination against women by men, so that this condition will become an obstacle to their progress. Violence against women, in this case related to dating violence, is one of the social mechanisms that needs attention, because it encourages women in a subordinate position compared to men. The purpose of this study is to find out how the concept and form of the criminal act of Dating Violence is. In addition, this study also aims to find out how the victimization of dating violence is reviewed and legal protection for victims of dating violence.
\end{abstract}

Keywords: Dating Violence, Crime, Women Protection, Victimology

The Indonesian Journal of International Clinical Legal Education DOI: https://doi.org/10.15294/ijicle.v3i3.48265

Submitted: Feb 12, 2021 Revised: April 15, 2021 Accepted: August 6, 2021 Available online at https://journal.unnes.ac.id/sju/index.php/iccle

(C) 2021 Authors. This work is licensed under a Creative Commons AttributionShareAlike 4.0 International License (CC BY-SA 4.0). All writings published in this journal are personal views of the authors and do not represent the views of this journal and the author's affiliated institutions. 


\section{INTRODUCTION}

Komnas Perempuan's 2019 Annual Record, Komnas Perempuan noted that there were 279,760 cases of violence against women consisting of 263,285 cases sourced from case data/cases handled by 359 Religious Courts (BADILAG data), as well as 16,403 cases handled by 195 service provider partner institutions, spread over in 31 provinces. Among them are 6 provinces with a high number of cases, namely: DKI Jakarta $(2,881)$, North Sumatra $(2,023)$, West Java $(1,846)$, East Java $(1,539)$, Central Java $(1,495)$, and Lampung $(1,326)$.

In fact, in 2020 violence that occurred in the personal realm was recorded as the highest case. A total of 11,719 cases in the personal realm, $64 \%$ or 7,548 cases of violence against wives, $21 \%$ or 2,507 cases of violence in dating, $7 \%$ or 844 cases of violence against girls, and $6 \%$ or 667 cases of violence in other personal relationships. Physical violence still ranks the highest this year, reaching 4,631 (39\%), in second place, psychological violence at 3,344 (29\%), sexual violence at 2,995 (26\%), and economic violence reaching 749 (6\%).

Among the types of violence that occur, dating violence has received much attention because of its broad nature and impact on the lives of women in particular and society in general. This type of violence has its roots in cultural factors that place women in an unequal position in relation to man. This is recognized by the international community as stated in the United Nations (UN) Declaration on the Elimination of Violence against Women (hereinafter referred to as the Declaration of Violence). In accordance with Article 1 of the 1993 United Nations Declaration on the Elimination of Violence against Women, it is stated that the definition of violence against women, is: "any act based on gender (gender based violence) that results in physical, sexual or psychological harm or suffering to women, including threats certain acts, coercion or arbitrary deprivation of liberty whether occurring in public or in private life".

Violence against women is a manifestation of the historical inequality of power relations between men and women. This results in the emergence of domination and discrimination against women by men, so that this condition will become an obstacle to their progress. Violence against women, in this case related to dating violence, is one of the social mechanisms that needs attention, because it encourages women in a subordinate position compared to men.

This then gave rise to many cases of harassment and violence in courtship which are still happening to this day, which take advantage of the weak position and the lack of advocacy and empowerment of women. Although the struggle for justice and equality has been carried out for a long time, equality in human relations has not yet reached the ideal stage. 
Women as marginalized people still experience subordination, discrimination, harassment, marginalization, violence, exploitation, etc. This means that the violence experienced by women takes many forms, be it psychological, physical, sexual, or economic. cultural and religious, to those that are part of a very large and powerful transnational organizing system.

Violence is a form of crime. Violence as stated by Galtung is an act by one or more persons that causes injury, both physically and nonphysically to another person, and furthermore is an act that causes a person to be unable to actualize himself, caused by forms of oppression and oppression. addressed to him. That is, violence causes a person to be harmed, or experience negative impacts in various forms. ${ }^{1}$

The forms of violence that befall women are present in all types of social relationships, including in family relationships, close friendships, in work relationships, as well as in social relations in society in general. Violence can happen to women anywhere, whether it is in public or private spaces, takes place both in communities that live in peace, or in societies that are during turmoil of war or armed conflict. absolutely safe for women.

The most common forms of violence against women are categorized into three types, namely physical, psychological, and sexual violence. Physical violence is violence that leaves real marks on the victim's body such as punches, kicks, slaps, cigarette burns and so on. Meanwhile, psychological, or emotional violence, such as verbal abuse, yelling, harsh words, threats to leave, excessive jealousy and so on. Meanwhile, sexual violence can be in the form of obscene remarks related to sex, touching body parts sexually against the victim's wishes, to forcing sexual intercourse with promises or coercion. There is also what is called economic violence, for example requiring one party to always spend money or prohibiting work.

Ideally, in a courtship relationship between a man and a woman, a relationship that respects, loves, accepts, and supports each other is established. But in fact, the reality is not as beautiful as it should be. It turns out that violence is also experienced by women from their partners. Ironically, often these women accept the violence they experience and consider the violence they experience as normal, and some even consider it a romantic and natural thing. ${ }^{2}$

1 Muladi \& Barda Nawawi Arief, Bunga Rampai Hukum Pidana, PT Alumni, Bandung, 2007, pp. 122-123.

2 G. Widiartama, Viktimologi Perspektif Korban dalam Penanggulangan Kejahatan, UAJY Press, Yogyakarta, 2009, pp. 87-88. See also Ackard, D. M., \& NeumarkSztainer, D. (2002). Date violence and date rape among adolescents: Associations with disordered eating behaviors and psychological health. Child abuse \& neglect, 26(5), 455-473; Kurtz, S. P., Surratt, H. L., Inciardi, J. A., \& Kiley, M. C. (2004). Sex work and "date" violence. Violence against women, 10(4), 357-385. 


\section{THE CONCEPT AND VARIOUS FORMS OF CRIMES IN ROMANCE RELATIONSHIP}

The Big Indonesian Dictionary defines courtship as follows: A boyfriend is a lover or friend of the opposite sex who is permanent and has a relationship based on love. Dating is making love; (or) make love (with the girlfriend). To date is to date; (or) make him a girlfriend.

The definition of dating as a permanent friendship between the opposite sex and having a foundation of love outside of marriage also does not include same-sex relationships. So, to be more precise, dating is a series of joint activities characterized by intimacy (such as a sense of ownership and self-disclosure) as well as an emotional attachment between unmarried men and women with the aim of getting to know each other and seeing the suitability of each other as a consideration before marriage.

Violence is the threat or use of physical force against another person, himself, a group, or community with the end result of injury or death, including murder, suicide, assault, sexual violence, rape, molestation and domestic violence. ${ }^{3}$ Dating violence is "the perpetration or threat of an act of violence by at least one member of an unmarried couple on the other member within the context of dating or courtship. This violence includes any form of sexual assault, physical violence, and verbal or emotional abuse". ${ }^{4}$

Dating violence is any act based on gender differences that results in or is likely to result in physical, sexual, or psychological harm or suffering, including threats of certain acts, coercion or arbitrary deprivation of liberty, whether occurring in public or in private life. Forms of violence in dating can be categorized into sexual, physical, emotional, and economic violence. The following is an explanation of the categories of dating violence, namely: ${ }^{5}$

3 G. Widiartama, Viktimologi Perspektif Korban dalam Penanggulangan Kejahatan, UAJY Press, Yogyakarta, 2009, p. 268.

4 Gerald T Hotaling, \& David B Sugarman, "An analysis of risk markers in husband to wife violence: The current state of knowledge". Violence and Victims, Vol. 1 No. 2, 1986, pp. 101-124. For further comparison please also see Cauffman, E., Feldman, S. S., Jensen, L. A., \& Arnett, J. J. (2000). The (un) acceptability of violence against peers and dates. Journal of adolescent research, 15(6), 652-673; Symons, P. Y., Groër, M. W., Kepler-Youngblood, P., \& Slater, V. (1994). Prevalence and predictors of adolescent dating violence. Journal of Child and Adolescent Psychiatric Nursing, 7(3), 14-23.

5 Achie Sudiarti Luhulima, Pemahaman Bentuk-Bentuk Tindak Kekerasan Terhadap Perempuan dan Alternatif Pemecahannya. Jakarta, PT Alumni, 2000, pp. 11-12. 
1. Sexual abuse, such as touching unwanted intimate parts, forcing by force to have sexual intercourse, rape, and attempted rape, having sexual relations with people who are drunk or under the influence of alcohol or drugs. This includes forcing sexual intercourse without a safety device (condom) which causes fears of being infected with HIVAIDS, including forcing sexual intercourse, sexual harassment (touching, kissing, touching) without consent. Acts without consent or coercion are usually accompanied by threats of abandonment, suffering or threats of physical violence.

2. Physical abuse in general forms of physical violence include hitting, slapping, and killing. Physical abuse, including slapping, strangling, hitting, kicking, burning, grabbing, using weapons, threatening to use weapons, and limiting someone, kicking, pulling hair, pushing with all you might, slapping, punching, strangling, burning body parts or burning with cigarettes, forcing sex, using tools, or intentionally taking someone to a place that endangers safety. This is usually done because the victim does not comply with his wishes, or the victim is considered to have made a mistake.

3. Emotional Abuse This includes insulting, cursing, belittling, threatening, terrorizing, depriving property, alienating from family and friends, including possessiveness behavior such as excessive jealousy. It can be said that this behavior takes the form of a desire to control the victim by reducing self-confidence and the ability to be behaviorally independent. It also includes calling by nicknames that are not liked. This form of violence is usually rarely realized because it is invisible. But this violence will cause feelings of pressure, not free and uncomfortable. This form of non-physical violence is in the form of giving nicknames that contain ridicule; make someone a laughingstock; threatening, excessive jealousy, limiting their partner to do activities they like, extortion, isolating, prohibition of making friends, verbal abuse, prohibition of preening, prohibition of being friendly to others and so on.

4. Financial Abuse (Economic Violence) This includes taking the victim's money, withholding, or not providing the financial needs of the victim, controlling, and supervising the expenditure of money to a minimum, all with the aim of controlling the victim.

Thus, it can be concluded that dating violence is violence that occurs in intimate relationships based on feelings of love or liking outside the marriage relationship. It includes attitudes or acts of coercion, assault, destruction, control, and threats both psychologically, physically, sexually and economically, or a combination of the four, which can have negative impacts, such as hurting, injuring or degrading the victim. 


\section{DATING VIOLENCE IN VICTIMOLOGY PERSPECTIVE}

Basically, the development of science about victims of crime (victimology), cannot be separated from the birth of theories from Hans von Hentig, a criminologist in 1941 and Mendelsohn, in 1947. The thoughts of these two experts greatly influenced every phase of victimization development. The development of victimology to the current state of course did not occur by itself but has undergone various developments that can be divided into three phases. In the first stage, victimology only studies victims of crime, at this stage it is called penal or special victimology. Meanwhile in the second phase, victimology does not only examine the problem of crime victims, but also includes accident victims. This phase is known as general victimology. The third phase, victimology has developed more broadly, namely examining the problems of victims due to abuse of power and human rights. This phase is known as new victimology. ${ }^{6}$ Victimology is a study that aims to: a. Analyze various aspects related to victims. b. Attempts to provide an explanation of the causes of victimization. c. Develop a system of action to reduce human suffering. ${ }^{7}$

According to J.E Sahetapy, the scope of victimology includes how a person (can) become a victim who is determined by a victimization that is not always related to the problem of crime, including victims of accidents and disasters other than victims of crimes of abuse of power. ${ }^{8}$

The development of the science of victimology in addition to inviting the public to pay attention to the position of the victim also sorts out the types of victims so that various types of victims emerge, namely as follows:

a. Non-participating victims, namely those who do not care about crime prevention efforts.

b. Latent victims, namely those who have certain character traits that tend to become victims.

c. Participating victims, namely those whose behavior makes it easier for them to become victims.

d. False victims, namely those who become victims because of their own actions.

6 Made Darma Wede, Beberapa Catatan Tentang Korban Kejahatan Korporasi, dalam Bunga Rampai Viktimisasi. Bandung,: Eresco, 1995, p. 200.

7 Muladi \& Barda Nawawi Arief, Bunga Rampai Hukum Pidana. Bandung: PT. Alumni, 2007, p. 82

8 Dikdik M. Arief Mansur \& Elisatris Gultom. Urgensi Perlindungan Korban Kejahatan antara Norma dan Realita.Jakarta: PT. Raja Grafindo Persada, 2007, p. 44 
The typology of victims as stated above has similarities with the typology of victims identified according to the circumstances and status of the victims, as follows: ${ }^{9}$

a. Unrelated victims, namely victims who have nothing to do with the perpetrator, for example in the case of a plane crash. In this case, the responsibility lies entirely with the perpetrator.

b. Provocative victims, namely someone who actively encourages himself to be a victim, for example in the case of cheating, where the victim is also the perpetrator.

c. Participating victims, namely someone who does not act but with his attitude encourages himself to become a victim.

d. Biologically weak victims, namely those who have a weak physique that causes them to become victims.

e. Socially weak victims, namely those who have a weak social position which causes them to become victims.

f. Self-victimizing victims, namely those who are victims of crimes they have committed themselves, for example victims of drugs, gambling, abortion, prostitution.

In general, it is said that the relationship between the victim and the crime is the party who becomes the victim because of the crime, in other words, the party becomes the victim because another party commits the crime. This strong opinion is supported by the existing facts, although in practice there are developing dynamics.

In a romance relationship, the victim is the party who is harmed while the perpetrator is the party who takes advantage or harms the victim in courtship. Losses that are often received or suffered by the victim in courtship can be in the form of physical, psychological, mental, economic violence, self-esteem, sexual and so on. This is related to the status, position, position, typology of the victim in a courtship relationship. The description confirms that the victim of violence in courtship is the victim of violence.

This means that victims of dating violence are the real victims. Victims of dating violence are not guilty but merely as victims with causes such as unhealthy relationships in dating, the existence of a patriarchal culture that is still strong and certain characteristics both from victims and perpetrators who can trigger violence. According to Hentig as quoted ${ }^{10}$, he assumes that the role of the victim in causing a crime is:

a. the crime was intended by the victim to occur;

b. losses due to crime may be used by the victim to obtain greater profits;

9 Lilik Mulyadi, Kapita Selekta Hukum Pidana Kriminologi dan Victimologi.Jakarta: Djambatan, 2007, pp. 124-125

10 Rena Yulia, Viktimologi Perlindungan Hukum Terhadap Korban Kejahatan. Yogyakarta: Graha Ilmu, 2010. pp. 81-82 


\section{Salimi Muhammad Baindowi}

c. the result that harms the victim may be a collaboration between the perpetrator and the victim; and

d. losses due to crime actually do not occur if there is no provocation from the victim.

The relationship between the victim and the perpetrator can be seen from the level of guilt. According to Mendelsohn, based on the degree of guilt, victims are divided into 5 (five) types, namely:

a. who is completely innocent;

b. who become victims due to negligence;

c. who is as wrong as the perpetrator;

d. who is more guilty than the perpetrator;

e. where the victim is the only one guilty (in this case the perpetrator is acquitted).

In addition, there is a relationship based on the relationship with the target of the perpetrator's actions, which are as follows:

a. Direct victims, namely those who are directly the target of an object of the perpetrator's actions.

b. Indirect victims are those who, although they are not directly the targets of the perpetrator's actions, but also experience suffering or misery.

Victims in courtship have a functional role in the occurrence of violence. The perpetrator's actions or acts of violence committed by the perpetrator in a courtship can result in a partner or other person becoming a victim, as stated by Samuel Walker that the relationship between the victim and the perpetrator of a crime is a causal relationship. The result of the perpetrator's actions is a crime and the victim who is the object of the perpetrator's actions causes the victim to suffer because of the crime. the biggest impact is the loss or psychological impact. Victims of violence in dating may continue to feel overwhelmed by the treatment in the form of violence that befell them which can prevent them from carrying out activities in their daily lives.

For victims of dating violence, the occurrence of violence that befell them will cause trauma in the form of symptoms of fear, anxiety, suspicion, cynicism, depression, loneliness, and various other avoidance behaviors. Examples of women who are victims of dating violence, especially those who have experienced sexual violence. Fear is the thing that dominates the victim the most. This fear controls all his behavior, and affects all his actions. Even fear can disrupt sleep patterns, leading to insomnia and nightmares. Sleep disorders can lead to dependence on sleeping pills and sedatives can threaten his safety and even threaten his life.

Judging from the characteristics of the victims, in general the victims of dating violence are young women, aged between 12 and 18 years who are more often victims of violence perpetrated by acquaintances, friends, or girlfriends than older women. rarely go to 
places of worship, have many girlfriends, often date, and women who have experienced similar violence in the past are vulnerable to being victims.

The impact of violence in dating is not only physical but also psychological. Psychological impact can traumatize women to men. As a result, women are afraid to have relationships with men (frigid and vaginismus). The social impact of violence in dating also puts women in a weak position in relationships with men. Moreover, women who feel that they have given up their virginity usually feel inferior to have a relationship. Furthermore, the physical impact will result in an unwanted pregnancy and the partner is not willing to take responsibility. There are two possibilities, namely continuing the pregnancy or abortion. If you continue your pregnancy, you must be prepared to be a single parent. If you have an abortion, you must be prepared to bear the risks, such as bleeding, infection and even death. In addition, if there is sexual intercourse in courtship, women will be susceptible to sexually transmitted diseases (STDs).

\section{LEGAL PROTECTION FOR VICTIMS OF DATING VIOLENCE}

The law in Indonesia does not specifically regulate violence in dating. This is because the tradition of courtship which is identical to sexual activity and fondling that ignores one's own honor is considered not in accordance with legal norms, religious norms, and social norms in Indonesia. Although the Criminal Code does not find the term courtship, it does not mean that this issue is not regulated in the Criminal Code.

For example, in the case of dating violence, it can be seen in Decision No. 538/PID.B/2012/PN-SBG, in which the defendant is the girlfriend of the victim's witness. The defendant and the victim's witness had been in a relationship for almost 3 (three) years. One day out of jealousy, the defendant abused the victim's witness by using both the defendant's hands and feet and the defendant's mouth. The acts of abuse carried out by the defendant included grabbing the hair, dragging the witness, biting the hand, punching or slapping the face, chest, left and right arm, squeezing or pulling the breast of the victim witness and also strangling the victim's neck and kicking the victim's witness stomach. As a result of the abuse, the victim's witness experienced coughing, shortness of breath, the victim's hand was swollen, and the victim's witness was prevented from doing his job and had difficulty speaking. The victim's witness said that after he and the defendant had been dating for 2 (two) years, the defendant often abused the witness. For the act of abuse, the defendant was charged with Article 351 paragraph (1) of the Criminal Code. The Panel of Judges decided to sentence the defendant to 


\section{Salimi Muhammad Baindowi}

imprisonment for 10 (ten) months. Based on the decision, dating violence is seen as the same as other types of crime in general. Therefore, this type of crime is treated the same as other types of crime (classified as a general crime).

Protection for victims of violence in dating uses generally applicable legal provisions, namely:

a. the Criminal Code (KUHP). In cases of dating violence, in principle, the perpetrators can be threatened with legal sanctions with articles of the Criminal Code, including:

1. Article 351-358 of the Criminal Code for physical abuse;

2. Article 289-296 of the Criminal Code for obscenity;

3. Article 281-283 of the Criminal Code for sexual harassment;

4. Article 285 of the Criminal Code for rape;

5. Articles 532-533 of the Criminal Code for crimes against decency.

b. Law Number 23 of 2002 concerning Child Protection (Child Protection Law)

If the victim of dating violence is a minor, the perpetrator can be charged with the provisions based on the law. Based on the Child Protection Law, people who have sexual intercourse with children, even though it is done on the basis of consensual (in a courtship relationship), can be charged with Article 81 paragraph (2) in conjunction with paragraph (1) of the Child Protection Law, which in full reads: intentionally commits violence or threats of violence forcing a child to have intercourse with him or with another person, shall be punished with a maximum imprisonment of 15 (fifteen) years and a minimum of 3 (three) years and a maximum fine of Rp. million rupiah) and at least Rp $60,000,000.00$ (sixty million rupiah).

In addition to the protection obtained from the provisions of the law, women who are victims of dating violence can request legal assistance in defense or assistance to the service provider institution (Komnas Perempuan) according to the needs of the victim. Legal aid is given to emphasize the demand for something rights that have been recognized by law are still respected. One form of legal assistance is the existence of a defense or assistance to victims of violence in courtship from an advocate (access to legal counsel). The objectives of providing protection for witnesses and victims can be analyzed as follows):

a. Encourage victims of violence to participate in the investigation and prosecution processes by establishing a set of rules and procedures that enable them to feel physically and psychologically safe;

b. Provide a sense of security to witnesses and victims in providing information in every criminal justice process;

c. Protect witnesses and victims from violence, threats of violence, both physical and psychological, including threats to the economy of witnesses and/or victims; 
d. Reducing the trauma felt by witnesses and victims.

\section{CONCLUSION}

Dating violence is any act based on gender differences that results in or is likely to result in physical, sexual or psychological harm or suffering, including threats of certain acts, coercion or arbitrary deprivation of liberty, whether occurring in public or in private life. In general, the victims of dating violence are young women, aged between 12 to 18 years who are more often victims of violence. Forms of dating violence can be categorized into sexual, physical, emotional, and economic violence. Dating violence can result in losses Victims experience not only physical or material harm, but the greatest impact is psychological harm or impact. Protection against victims of dating violence uses the generally accepted legal provisions, namely the Criminal Code. If the victim of dating violence is a minor, the perpetrator can be charged with the provisions based on Law no. 23 of 2002 concerning Child Protection. In addition, women as victims are entitled to protection based on Law Number 13 of 2006 concerning the Protection of Witnesses and Victims.

\section{REFERENCES}

Ackard, D. M., \& Neumark-Sztainer, D. (2002). Date violence and date rape among adolescents: Associations with disordered eating behaviors and psychological health. Child abuse \& neglect, 26(5), 455-473.

Cauffman, E., Feldman, S. S., Jensen, L. A., \& Arnett, J. J. (2000). The (un) acceptability of violence against peers and dates. Journal of adolescent research, 15(6), 652-673.

Komisi Nasional Anti Kekerasan terhadap Perempuan. (2009). Perlindungan terhadap Saksi dan Korban. Jakarta: Komnas Perempuan

Kurtz, S. P., Surratt, H. L., Inciardi, J. A., \& Kiley, M. C. (2004). Sex work and "date" violence. Violence against women, 10(4), 357385.

Luhulima, A. S. (2000). Pemahaman Bentuk-Bentuk Tindak Kekerasan Terhadap Perempuan dan Alternatif Pemecahannya. Jakarta: PT Alumni.

Mansur, D. M. A., \& Gultom, E. (2007). Urgensi Perlindungan Korban Kejahatan antara Norma dan Realita. Jakarta: PT. Raja Grafindo Persada.

Muladi, M., \& Arief, B. N. (2007). Bunga Rampai Hukum Pidana. Bandung: PT. Alumni. 


\section{Salimi Muhammad Baindowi}

Mulyadi, L. (2007). Kapita Selekta Hukum Pidana Kriminologi dan Victimologi. Jakarta: Djambatan.

Soetjiningsih, S. (2004). Tumbuh Kembang Remaja dan Permasalahanya. Jakarta: Sagung Seto.

Symons, P. Y., Groër, M. W., Kepler-Youngblood, P., \& Slater, V. (1994). Prevalence and predictors of adolescent dating violence. Journal of Child and Adolescent Psychiatric Nursing, 7(3), 14-23.

Wede, M. D. (1995). Beberapa Catatan Tentang Korban Kejahatan Korporasi, dalam Bunga Rampai Viktimisasi. Bandung: Eresco.

Widiartana, G. (2009). Viktimologi, Perspektif Korban dalam Penanggulangan Kejahatan. Yogyakarta: Atmajaya.

Yulia, R. (2010). Viktimologi Perlindungan Hukum Terhadap Korban Kejahatan. Yogyakarta: Graha Ilmu.

\section{Conflicting Interest Statement}

All authors declared that there is no potential conflict of interest on publishing this article.

\section{Funding}

None

\section{Publishing Ethical and Originality Statement}

All authors declared that this work is original and has never been published in any form and in any media, nor is it under consideration for publication in any journal, and all sources cited in this work refer to the basic standards of scientific citation.

Cite this article as:

Baindowi, S. M. (2021). Dating Violence: A Report from Legal and Victimological Perspective. The Indonesian Journal of International Clinical Legal Education, 3(3), 245-256.

https://doi.org/10.15294/ijicle.v3i3.48265 